\title{
MAKNA TANDA DALAM INTERIOR RUANG TAMU: STUDI SEMIOTIKA SISTEM TERTUTUP PADA INTERIOR RUANG TAMU LIMA STATUS SOSIAL DI YOGYAKARTA
}

Guest room in Indonesian houses has a unique position compared with any other room. The owner of the house usually sets more decoration in the guest room as a mean to impress the guest. This tendency has a root in Indonesian traditional society where the guest has always been honored and treated well. This research aims to reveal the meaning of the guest room interior in five different social groups in Yogyakarta. Using semiotic analysis with closed system developed by Bonta, the five guest rooms are interpreted with local cultural reference that has been the source of the signs created by each social group. The result of this study showes that each social group has its own particular signs that can be associated with their social background. The study also reveals five binary-oppositional meanings which can be attached in each social group in a contrasting way. These meanings are simplicity-luxary, Elite-cammon, pride-humble, artistic-plain, idealistic- realistic, progressive-conservative, and private-public.

\section{Keywords: Social group, Meaning, Semiotic}

Ruang tamu sebagai ruang yang dapat diakses oleh publik dalam suatu wilayah pribadi merupakan ruang yang memiliki sifat khusus. Sifat khusus ini terlihat dari frekwensi pemakaian ruang yang berbeda dengan ruang lainnya. Ruang lain seperti ruang tidur, ruang keluarga dan ruang makan digunakan berdasarkan urutan waktu, meskipun dalam aturan yang longgar. Ruang makan digunakan pada jam waktu makan, ruang tidur digunakan pada jam tidur, sedangkan ruang keluarga digunakan pada jam berkumpul.

Sebagai ruang yang berfungsi untuk menerima tamu baik yang telah dikenal maupun tidak dikenal, ruang tamu pada umumnya terletak pada bagian depan rumah. Perletakan ini secara spasial menunjukkan bahwa ruang tamu merupakan ruang pertama yang akan dimasuki oleh "orang asing" di dalam wilayah pribadi.
Interaksi antara tamu dan pemilik rumah dalam ruang tamu merupakan interaksi sosial antar individu. Menurut Altman dan Taylor (1973) interaksi sosial antar individu memiliki beberapa tahap diantaranya adalah tahap penyingkapan pribadi dan identitas. Tahap ini merupakan tahap dimana masing-masing individu menyingkapkan dirinya melalui informasi dan pembicaraan ringan. Setiap individu menurut Berger (2000) dapat mengungkapkan identitasnya melalui tanda-tanda di sekitar dirinya.

Proses pertukaran tanda ini dapat terlihat dari cara berpakaian, bahasa, logat dan kepemilikan benda pribadinya. Pemilik rumah dalam hal ini dapat menggunakan ruang tamunya sebagai sarana untuk mengirim tanda kepada para tamunya. Proses bekerjanya tanda ini menurut Berger (2000) mirip dengan cara kerja detektif membaca petunjuk-petunjuk untuk

*Korespondensi penulis dialamatkan ke Program Studi Desain Interior, Fakultas Seni Rupa, Institut Seni Indonesia Yogyakarta, Telp/Fax: +62 274417219 e-mail: banu_art@yahoo.com 
mengungkapkan suatu kejahatan.

Tanda-tanda ini berperan sebagai petunjuk bagi orang lain untuk menyingkapkan siapa si pemilik tanda tersebut. Setiap tanda yang ditampilkan memiliki arti tertentu sehingga dapat ditafsirkan oleh penerimanya menjadi suatu pesan. Menurut Christian (1976) manusia adalah makhluk simbolis yang senantiasa mencari makna. Makna merupakan konsep yang diciptakan manusia dan dilekatkan pada tanda-tanda sehingga dapat dipakai untuk mengkomunikasikan sesuatu.

Masyarakat tradisional maupun modern memiliki tanda-tanda yang melekat pada benda-benda yang dimilikinya seperti perhiasan, pakaian, kendaraan dan rumah tinggal. Masyarakat tradisional Indonesia seperti masyarakat Toraja telah mengenal tanda pada arsitektur tradisionalnya untuk menandai status sosial dan identitasnya. Mereka menandai identitas dan status sosialnya dengan jumlah tiang penyangga di rumahnya (Sumintardja, 1978). Semakin banyak tiang penyangga rumah semakin tinggi status sosial pemilik rumah tersebut. Interior rumah tradisional Jawa juga memiliki ruang yang dapat menunjukkan status dan identitas sosialnya. Sumintardja (1978) menjelaskan bahwa "senthong tengah" pada rumah Jawa digunakan sebagai "ruang pamer" bagi penghuninya. Hal ini menunjukkan bahwa interior rumah tinggal digunakan untuk mengkomunikasikan identitas dan status, terutama pada ruangruang yang dapat dilihat oleh tamu.

Masyarakat modern juga memiliki tanda-tanda pada arsitektur dan interior rumah tinggalnya. Conran (1994) menegaskan bahwa pemilik rumah sebaiknya jujur dan merasa bebas untuk mengekspresikan siapa dirinya dalam interior rumahnya. Kebebasan untuk mengekspresikan diri melalui tanda pada masayarakat modern memiliki perbedaan dengan masyarakat tradisional yang terikat pada simbol konvensional. Meleburnya batas-batas budaya pada era globalisasi telah mengaburkan kejelasan tanda-tanda pada budaya kontemporer. Masyarakat dari satu kebudayaan dapat meminjam tanda dari kebudayaan lain untuk menunjukkan identitas dan statusnya.
Kelompok-kelompok sosial dalam masyarakat modern berusaha menunjukkan identitasnya melalui tanda-tanda. Contoh yang menonjol dari kelompok sosial yang menunjukkan identitasnya secara mencolok adalah kelompok Punk di Inggris dan kelompok pengendara motor besar di Amerika Serikat (Berger, 2000).

Masyarakat modern di perkotaan pada umumnya merupakan masyarakat heterogen yang memiliki profesi dan latar belakang yang berbeda-beda. Kota besar seperti Yogyakarta yang dikenal sebagai kota pendidikan dan pariwisata telah menarik minat para pendatang untuk melanjutkan pendidikan, berwisata dan mencari nafkah. Sebagai kota dengan penduduk heterogen Yogyakarta memiliki kelompok sosial dan peran sosial beragam dalam struktur masyarakatnya.

Kelompok sosial sebagai bagian dari budaya tertentu masih menganut unsur-unsur budaya induknya. Budaya induk ini menjadi payung utama yang menuntun tiap kelompok untuk berinteraksi dalam kelompok yang lebih besar (Scupin dkk, 1997). Kebudayaan induk bukanlah hal yang mutlak seragam sehingga dalam kehidupan sehari-hari kita dapat menjumpai perbedaan-perbedaan tiap individu dalam pelaksanaan aturan-aturan budaya. Hal serupa juga terjadi dalam kebudayaan turunan yang berkembang dalam kelompok sosial tertentu sehingga tetap terjadi keragaman dalam budaya turunan tersebut.

Tanda-tanda dalam kelompok sosial yang digunakan untuk menunjukkan identitas secara umum memiliki kesamaan, namun demikian tiap individu juga memiliki perbedaan dalam mengungkapkannya. Penelitian ini bertujuan untuk mengungkap makna tanda-tanda yang sama pada lima peran sosial dalam menunjukkan identitas dirinya. Selain kesamaan makna tanda, perbedaan makna setiap individu juga akan diungkap untuk melihat variasi pemakaian tanda dalam satu kelompok. Secara praktis penelitian ini dapat dimanfaatkan oleh desainer untuk memodifikasi tanda dengan memahami maknanya sehingga dapat diterapkan pada desain interior sejenis. 


\section{Semiotika}

Kata Semiotika menurut Walker (1989) berasal dari bahasa Yunani "Semeion" yang berarti "tanda". Tanda dalam konteks Semiotika memiliki arti yang luas dibandingkan dengan pengertian tanda sehari-hari. Menurut Pierce dalam Walker (1989) tanda adalah "sesuatu" yang dapat menggantikan "seseorang" atau "sesuatu yang lain" dalam kapasitas tertentu.

Selain Pierce dan Saussure terdapat peneliti lain bidang Semiotika yang mengembangkan relasi antara petanda dan penanda. Bonta (1979) mengembangkan penelitian Semiotika bidang arsitektur dengan memodifikasi relasi penandaan yang dikembangkan oleh dua ahli sebelumnya. Bonta (1979) mengganti istilah tanda dengan indikator yang secara konseptual memiliki fungsi yang sama dengan tanda. Indikator merupakan "sesuatu" yang menunjukkan "sesuatu yang lain".

Contoh indikator adalah adanya antrian kendaraan di jalan bebas hambatan yang menunjukkan adanya kecelakaan lalu litas. Indikator menurut Bonta (1979) dapat berupa kumpulan kejadian ataupun benda yang secara keseluruhan memperkuat makna yang ditimbulkannya. Sebagai contoh antrian kendaraan, jika diperkuat dengan bunyi raungan sirene polisi dan ambulan akan memperkuat arti dari indikator tersebut yaitu adanya kecelakaan lalu lintas. Bonta (1979) mengambarkan klasifikasi indikator sebagai berikut :lihat Tabel 1 dengan sengaja oleh pengirim dan diterima sesuai dengan maksud pengirimnya. Jenis indikator yang terbaca langsung namun tidak sengaja proses pengirimannya disebut pseudo-signal atau sinyal semu.

Sinyal semu dapat disamakan dengan bahasa tubuh manusia ketika sedang berkomunikasi. Bahasa tubuh dapat ditangkap secara langsung oleh penerima pesan meskipun si pengirim tidak bermaksud untuk melakukannya. Seseorang yang berbohong seringkali mengeluarkan keringat dingin yang dapat dilihat oleh lawan bicaranya sebagai tanda kegugupan.

Kelompok indikator kedua memiliki nama yang sama dengan kategorisasi Pierce namun memiliki pengertian yang berbeda. Intentional index adalah tanda yang dikirim langsung oleh pengirim pesan namun hanya bisa terbaca melalui indikasi atau petunjuk tak langsung. Jenis tanda yang terakhir adalah index yang dikirimkan secara tidak sengaja dan dibaca melalui indikasi yang menunjuk pada makna tertentu.

Index menurut Bonta (1979) adalah tanda yang ada pada suatu kondisi tertentu. Contoh antrian kendaraan diatas adalah merupakan jenis tanda index karena muncul dari situasi yang tidak disengaja atau dibuat. Pengamat yang melihat antrian tersebut hanya bisa menduga melalui indikasi umum bahwa antrian tersebut biasanya menandakan adanya kecelakaan di jalan. Orang yang tidak terbiasa dengan aktifitas dan kejadian-kejadian di jalan raya tidak akan

Tabel 1. Kategorisasi Indikator Menurut Bonta (Sumber : Bonta, 1979)

\begin{tabular}{|c|c|c|}
\hline Pengirim & Terbaca secara langsung & Terbaca melalui indikasi tak langsung \\
\hline Sengaja di kirimkan & Signal & Intentional index \\
\hline Tidak disengaja & Pseudo-signal & Index \\
\hline
\end{tabular}

Klasifikasi yang dikembangkan Bonta (1979) ini menekankan pada hubungan antara pengirim tanda dan penerimanya. Selain itu terdapat pula penekanan pada bagaimana tanda tersebut dihasilkan. Signal merupakan jenis indikator yang dikirimkan mampu mengartikan tanda-tanda yang ada. Makna dengan demikian merupakan domain kultural yang hanya bisa dipahami dengan pemahaman kultural di sekitar tanda tersebut (Bonta, 1979).

Makna menurut Berger (2000) dapat 
dipahami dengan menggunakan oposisi biner yang dipakai oleh Levi Strauss dalam mengartikan budaya. Oposisi biner menurut Appiganesi (1999) merupakan prinsip bekerjanya pikiran manusia yang selalu mencari pasangan kata berlawan atau konsep yang berpasangan.

Oposisi biner menurut Berger (2000) dapat digunakan untuk menganalisis maknamakna yang muncul dalam satu narasi seperti film atau naskah. Sebuah cerita memiliki makna yang muncul dari pertentangan tokoh ataupun simbol yang muncul didalam alurnya. Contoh oposisi biner yang paling menonjol adalah pertentangan antara baik-buruk, keadilan-kesewenangwenangan, cantikjelek, kaya-miskin.

Eco (1979) menjelaskan bahwa makna dapat diterjemahkan dengan melihat referensinya, namun demikian referensi tersebut adalah sebuah konstruksi budaya sehingga berbentuk abstraksi. Jika seseorang menyebut kata "kejahatan" maka artinya dapat bervariasi antar kebudayaan.

Lawson (2001) menegaskan bahwa manusia cenderung mencari makna dari stimulus visual yang dijumpainya. Hal ini disebabkan karena stimulus visual yang komplek cenderung sulit untuk diingat sehingga manusia mencari makna agar dapat disimpan dalam memorinya. Konsep sistem tertutup ( closed system ) dalam analisis semiotika diperkenalkan oleh oleh Bonta (1979) sebagai alternatif analisis sistem ekspresi dalam arsitektur. Sistem tertutup memungkinkan pembaca untuk membaca tanda dalam satu tolok ukur terbatas sehingga tidak menimbulkan bias subyektif berlebihan.

Bonta (1979) menegaskan bahwa tiap pembaca dapat memilih sistem yang dipakainya untuk membaca tanda yang ada. Sebagai contoh Monas dapat diletakkan dalam sistem tertutup dengan meletakkannya dalam satu kategori dengan Menara Pisa, dan Menara Eiffel. Perletakan dalam sistem tertutup ini memungkinkan pembaca untuk menganalisis bahwa Monas terlihat masif dindingnya dibandingkan kedua menara tersebut.

Sistem ini sebetulnya merupakan reaksi dari pandangan Atomis yang menyatakan bahwa tanda dapat berdiri sendiri tanpa konteks yang melingkupinya. Para pendukung aliran Atomis memberikan contoh bidak catur yang selalu dapat dikenali meskipun tidak berada dalam papan catur. Bonta (1979) memberikan argumen bahwa kelompok Atomis memiliki kelemahan jika sistem penandaannya diubah. Bidak catur yang berbentuk kuda memang selalu dapat dilihat sebagai bidak kuda meskipun berada diluar papan. Persoalannya menjadi lain jika semua bidak catur diubah bentuknya menjadi binatang maka bidak kuda dapat diletakkan pada posisi raja.

Posisi bidak dalam sistem papan caturlah yang menentukan peran dan arti bidak tersebut, bukan bentuk tandanya. Analisis dengan pandangan Atomis hanya dapat dilakuakan pada sistem yang telah stabil dan mantap karena jika sistemnya berubah-ubah maka makna tandanya berubah pula.

Peran sosial menurut Susanto (1979) memiliki keterkaitan erat dengan status sosialnya, hal ini disebabkan karena status sosial tidak ada artinya jika tidak dipergunakan atau diperankan dalam suatu hubungan sosial. Lebih lanjut Susanto (1979) menjelaskan bahwa status merupakan kedudukan obyektif individu dalam masyarakat yang memungkinkan individu untuk memiliki hak dan kewajiban yang melekat pada dirinya. Status ini akan tampak jika individu yang memiliki status menjalankan perannya dalam masyarakat. Status dan peran sosial memilki keterkaitan erat

Selanjutnya menurut Linton dalam Susanto (1979) menjelaskan status sosial terdiri dari dua macam yaitu : ascribed status dan achieved status.

Ascribed Status adalah status sosial yang diperoleh berdasarkan wewenang atau kekuasaan resmi. Status ini diberikan dengan pengesahan dari pihak yang memiliki otoritas sehingga pemilik status dapat mempergunakan hak dan kewajibannya secara formal. Sedangkan Achieved Status adalah status sosial yang dicapai seseorang berdasarkan kemampuan yang dimilikinya. Achieved Status memerlukan syarat-syarat tertentu dari individu untuk dapat mendapatkannya.

Peran sosial dalam masyarakat agraris menurut Scupin dkk (1992) terbentuk 
dengan berbagai cara diantaranya melalui pembagian tugas untuk mencapai harmonisasi. Pembagian tugas ini memungkinkan masyarakat agraris saling berintegrasi dan mengurangi konflik diantara mereka. Scupin dkk (1992) menjelaskan pula bahwa peran sosial dalam masyarakat membantu menciptakan berdirinya suatu negara yang meliputi kesatuan sistem sosial, ekonomi dan pertahanan. Pilar dasar yang menyangga masyarkat agraris adalah pertanian sehingga jika kebutuhan pertanian telah terpenuhi anggota masyarakat dapat menjalankan peran lainnya seperti seniman, pemuka agama, pedagang dan tukangtukang.

\section{BAHAN DAN METODE}

Obyek dalam penelitian ini adalah tanda-tanda yang terdapat dalam ruang tamu lima status sosial di Yogyakarta. Setiap status sosial diwakili oleh tiga individu sehingga jumlah keseluruhan ruang tamu yang diteliti adalah lima belas.

Kelima peran sosial yang dipilih tersebut adalah: Kiai, Pengusaha, Pejabat, Staf TNI, dan Seniman. Kelima status sosial ini dipilih karena keberadaan mereka memiliki posisi penting dalam masyarakat. Peran yang dimainkan oleh kelima status sosial ini mewakili unsur sosial-budaya, ekonomi, politik dan pertahanan. Kelima unsur ini menurut Suhady (2003) merupakan unsur yang mewakili wawasan kebangsaan dalam kehidupan berbangsa dan bernegara di Indonesia.

Data mengenai tanda-tanda dalam interior ruang tamu diperoleh dengan observasi di lapangan dengan memakai kamera foto digital. Tanda-tanda ini meliputi tanda yang berfungsi sebagai asesoris dan perabot. Data Tata letak ruangan diperoleh dengan melakukan pengukuran langsung dilapangan.

Data Konsep interior ruang tamu diperoleh melalui wawancara langsung dengan pemilik rumah. Wawancara dilakukan dengan pedoman wawancara yang terdiri dari tiga kategori pertanyaan yaitu : keinginan pemakai dan stabilitas tanda.

Tanda-tanda dalam interior tersebut dianalisis dengan mengadopsi analisis sistem tertutup dari Bonta (1979) yaitu dengan menempatkan tanda dalam satu kelompok dan melihatnya berdasar norma kelompok sehingga diperoleh interpretasi yang didasarkan pada kondisi obyektif. Makna tanda dianalisis berdasarkan konteks budaya yang secara umum dianut oleh masyarakat pengguna tanda, yaitu pencipta dan pembacanya.

Data konsep ruang tamu yang didapat melalui wawancara dianalisis dengan menggunakan analisis tematik sehingga ditemukan tema-tema yang mewakili konsep ruang tamu tiap status sosial. Konsep ini digunakan untuk menganalisis kategori tanda sesuai dengan sistem yang dianut Bonta (1979) yaitu : Signal, Pseudo-Signal, Intentional Index dan Index.

\section{HASIL PENELITIAN DAN PEMBAHASAN}

Peran status sosial yang pertama diamati adalah Kiai. Kiai sebagai pemuka agama dalam komunitas muslim memiliki kecenderungan untuk hidup sederhana dibandingkan dengan kelompok status sosial lainnya. Hal ini terlihat dari unsur pembentuk ruang yang terdapat di rumah-rumah kiai. Lantai, dinding dan langit-langit rumah kiai terbuat dari bahan sederhana dan terkesan apa adanya. Lantai tegel sebagai index menunjukkan indikasi bahwa kiai tidak berusaha untuk "up to date" dengan mengganti dengan lantai keramik.

Langit-langit yang menggunakan bahan
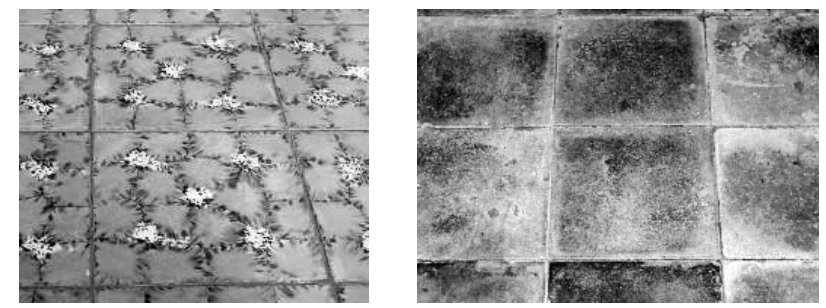

Gambar 1. Jenis Penutup Lantai Ruang Tamu Kiai 
LINTAS

RUANG | VOL.2 | EDISI 2 | 2008

ISSN 1978-0702

ekspose "kepang" juga menunjukkan indikasi bahwa kiai tidak berusaha menampilkan sisi artistik bahan seperti yang terdapat di rumah seniman. Hal ini dapat diartikan sebagai sikap kesederhanaan kiai dalam mengolah bentuk fisik ruang tamunya.

Hal lain yang menarik dari ruang tamu kiai adalah penggunaan "hijab" di ruang tamu.
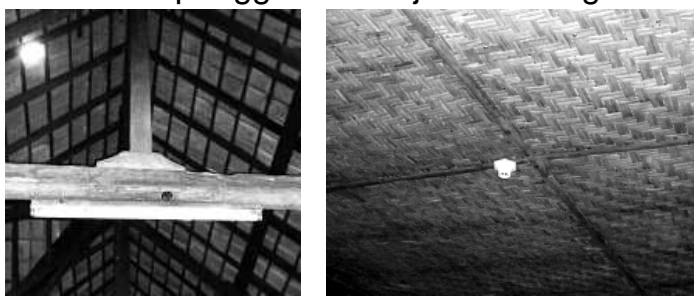

Gambar 2. Plafond Ruang Tamu Kiai

dianutnya dengan mendesain ruang tamunya sesuai dengan ajaran Islam. Tidak semua kiai menggunakan hijab fisik dalam ruang tamunya beberapa kiai memakai cara lain seperti harus ditemani oleh orang beberapa orang jika tamunya adalah lawan jenisnya.

Tanda yang berupa Signal juga terlihat dari pemasangan simbol-simbol agama baik berupa logo, foto maupun kaligrafi. Tandatanda ini merupakan Sianal vana dapat

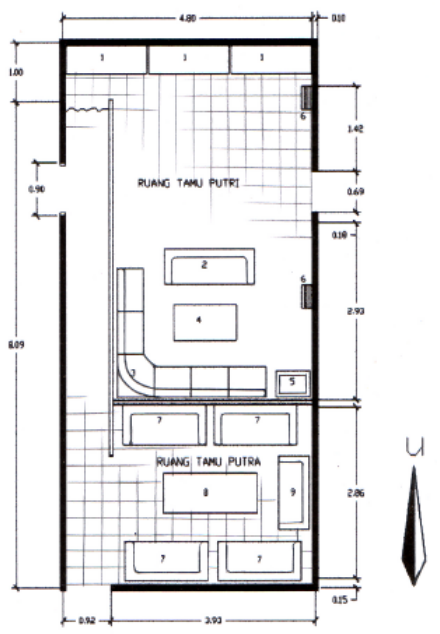

Gambar 3. Denah Ruang Tamu Kiai dengan Hijab

menunjukkan kemewahan dibandingkan dengan kelompok status sosial lainnya.

Desain yang diterapkan di ruang tamu tamu pengusaha juga memiliki kecenderungan untuk menampilkan kemegahan seperti pemakaian langit-langit tinggi, lampu hias mewah dan kolom-kolom Yunani. Pemakaian bahan dan desain ini dapat dikategorikan sebagai Signal yang ditangkap langsung sebagai indikasi kemewahan dalam ruang tamu pengusaha.
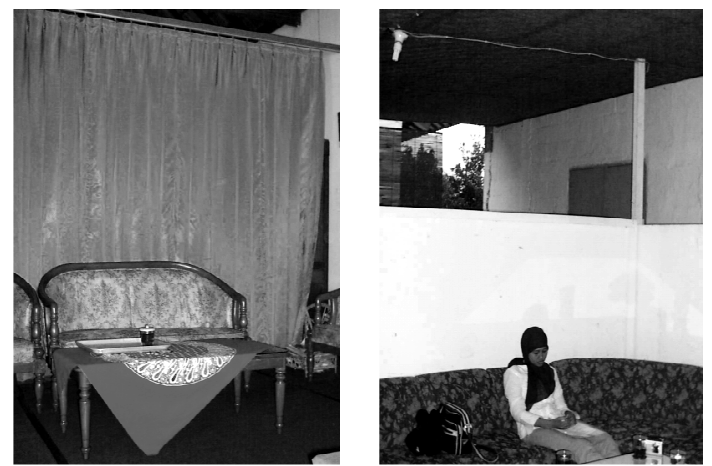

Gambar 4. Berbagai Macam Bahan Hijab

Tanda lain yang terdapat di ruang tamu pengusaha adalah foto diri yang cenderung menampilkan foto keluarga dan foto wisata. Berbeda dengan kelompok lain yang cenderung menampilkan foto diri dalam identitas (kiai dengan sorban, TNI dengan seragam, pejabat dengan seragam) pengusaha biasanya berfoto dengan pakaian daerah atau setelan jas.
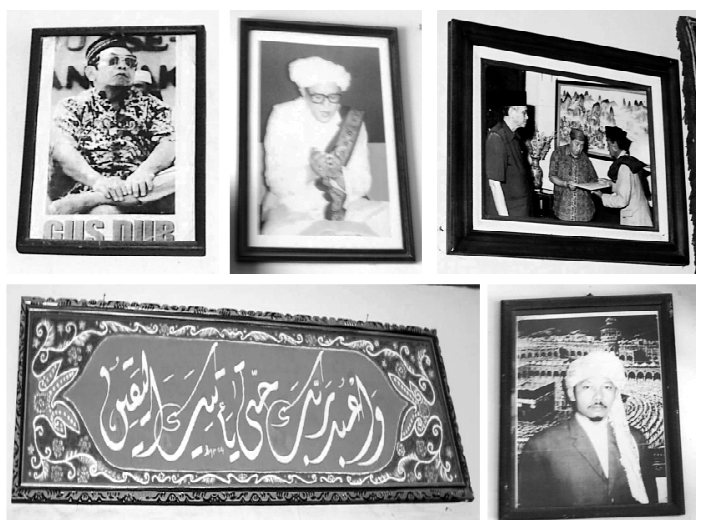

Gambar 5. Berbagai Macam Asesoris di Ruang Tamu Kiai 
Foto lain yang dipasang di ruang tamu pengusaha adalah foto wisata di tempattempat terkenal di dunia. Hal ini dapat diartikan sebagai kebanggaan atas keberhasilannya dalam bisnis atau usahanya. Masyarakat Indonesia menganggap bahwa jas adalah pakaian mahal yang hanya dipakai oleh kalangan tertentu dengan uang berlebih, demikian pula dengan liburan ke luar negeri. Dibandingkan dengan kelompok kiai, pengusaha lebih cenderung untuk menunjukkan "tempat berfoto" daripada "dengan siapa berfoto". Hal ini kemungkinan disebabkan karena pengusaha merupakan individu yang selalu mengejar kesuksesan secara mandiri sehingga kebanggaannya merupakan kebanggaan pribadi atas pencapaian hasil usahanya.
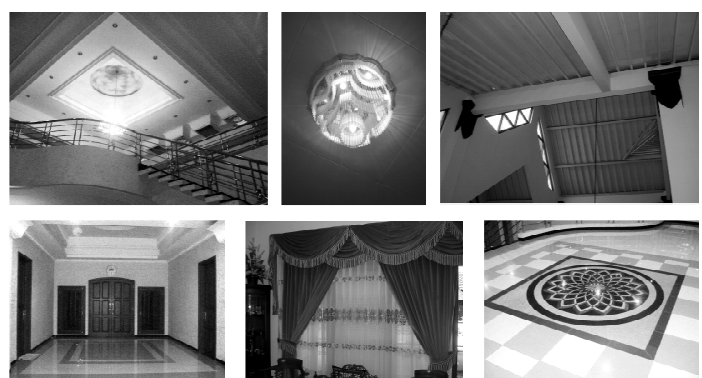

Gambar 6. Unsur Pembentuk Ruang Interior Ruang Tamu Pengusaha kecenderungan untuk menampilkan kemapanan dibandingkan dengan kemewahan yang ditampilkan oleh kelompok pengusaha.

Kemapanan ini terlihat dari pemilihan bahan perabot dan desain ruang tamu yang cenderung konvensional. Berbeda dengan kelompok seniman, pengusaha dan kiai yang cenderung "membedakan diri" dengan penataan ruang yang unik, pengusaha memilih desain yang "umum" dan "aman" tanpa penekanan pada satu konsep khas. Kecenderungan ini memiliki kesamaan dengan kelompok staf TNI. Hal ini kemungkinan disebabkan karena keduanya berasal dari kelompok yang well-established baik dari segi sosial maupun ekonomi.

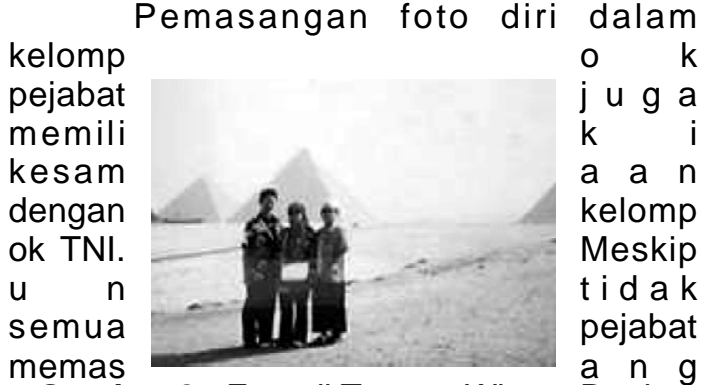

f Gambar 8. Foto di Tempat Wisata Qipnizay dalam seragam dinasnya, beberapa pejabat menunjukkan jati dirinya dengan memasang foto dengan pakaian seragam dinas lengkap. Hal ini menunjukkan kebanggan akan status sosial yang disandangnya. Kebanggaan ini juga ditunjukkan dengan memajang plakatplakat yang mencerminkan prestasi diri.

Hal lain yang menunjukkan posisi status sosial yang tinggi adalah pemajangan benda-benda seni. Berbeda dengan seniman yang memajang benda seni sebagai cerminan ide kreatifnya, pengusaha

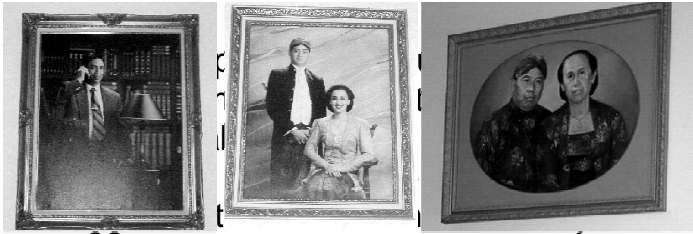

menonjol yagambermbectakrandrikmah tinggal pejabat dan pengusaha adalah 

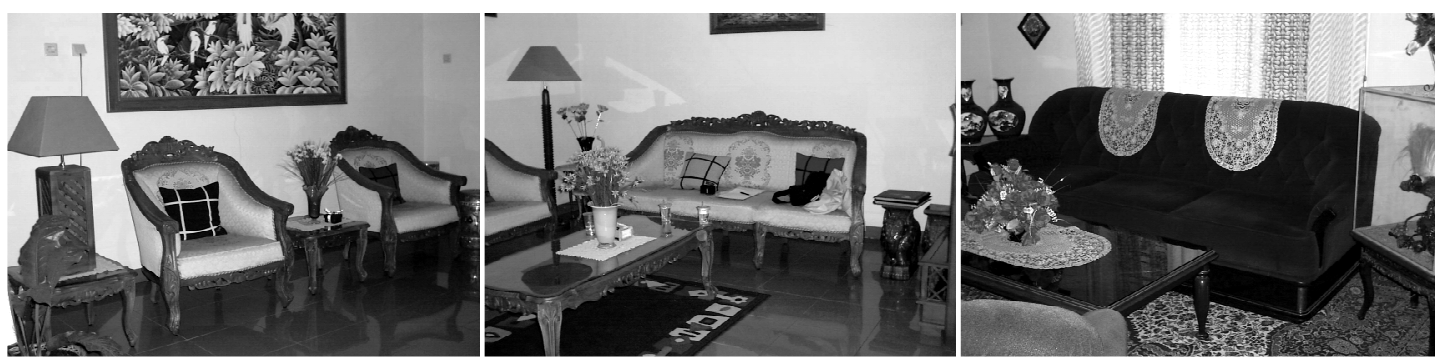

Gambar 9. Suasana Interior Ruang Tamu Pejabat

cenderung memajang benda seni karena faktor keserasian dan penghias ruang. Secara umum benda-benda seni ini memiliki harga relatif mahal bagi kebanyakan masyarakat Indonesia sehingga pemasangan benda-benda seni ini menunjukkan kemampuan finansial dan selera artistik dari para pejabat tersebut.

Rasa keindahan bagi kalangan pejabat dianggap sebagai hal yang mendukung status sosial yang disandangnya. Hal ini terlihat dari kecenderungan pejabatpejabat di Indonesia yang gemar mengkoleksi

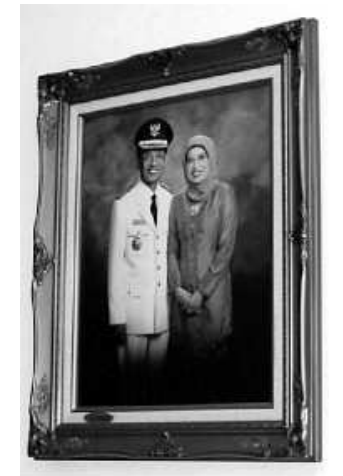

hasil-hasil karya seniman-seniman tertentu. Meskipun hasil karya seni tesebut seringkali merupakan hadiah dari sang seniman, keberadaannya tetap menunjukkan ketinggian status sosial pejabat karena tidak semua orang mendapat hadiah dari seniman.

Seperti halnya kelompok kiai, kelompok pejabat juga memasang kaligrafi sebagai penunjuk identitas agamanya. Beberapa pejabat memasang kaligrafi dengan material dan desain berkualitas tinggi. Hal ini menunjukkan bahwa kelompok pejabat tidak semata-mata memasang kaligrafi sebagai identitas agama melainkan juga sebagai penunjuk status sosialnya.(lihat Gambar 12)

Unsur pembentuk ruang di ruang tamu kelompok staf TNI tidak memiliki keistimewaan dibandingkan dengan kelompok seniman ataupun kiai. Dinding, lantai dan langit-langitnya memiliki kemiripan dengan kelompok pejabat dan pengusaha. Keunikan yang terdapat di ruang tamu pengusaha terlihat pada pemasangan

\section{Gambar 10. Foto dalam Seragam Dinas}
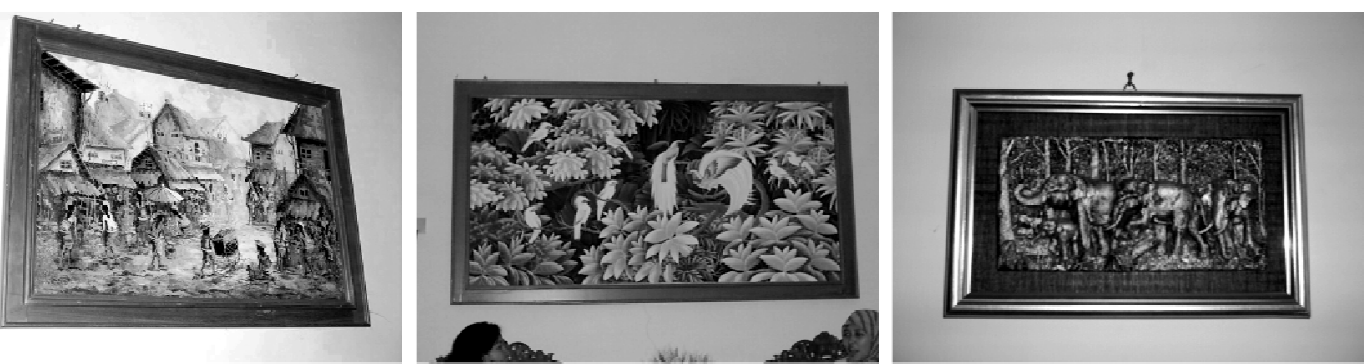

Gambar 11. Beberapa artwork di Interior Ruang Tamu Pejabat 
asesoris dan foto diri. Asesoris berupa senjata baik dalam bentuk senjata tradisional maupun senjata modern terlihat di seluruh ruang tamu staf TNI yang diteliti.

Signal ini menunjukkan identitas profesi kelompok TNI yang sehari-harinya berhubungan dengan persenjataan dan pertahanan. Selain identitas profesi pemasangan asesoris senjata ini juga menunjukkan ekslusifitas. Asesoris berupa peluru artileri dan peluru kaliber kecil tidak dapat dimiliki begitu saja, hal ini berhubungan dengan ketatnya peraturan mengenai kepemilikan senjata api di Indonesia. Memiliki benda-benda "langka dan berbahaya" tersebut dapat dimaknai sebagai kekhususan dalam masyarakat Indonesia.

Menjadi anggota TNI memang merupakan kebanggaan tersendiri dalam masyarakat Indonesia. Hal ini berhubungan dengan kekuasaan dan superioritas yang

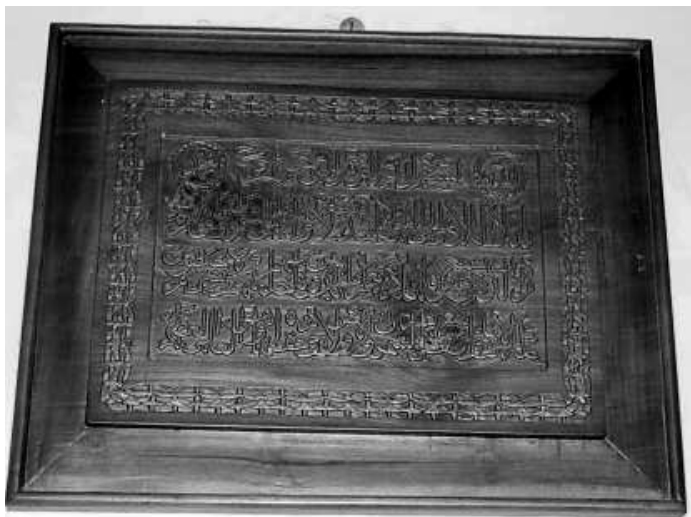

Gambar 12. Kaligrafi dari Ukiran Kayu dimiliki oleh anggota TNI dalam masyarakat Indonesia. Meskipun dalam era Reformasi kekuatan TNI tidak sedominan era Orde baru, menjadi anggota TNI tetap menjadi kebanggaan bagi sebagian besar masyarakat Indonesia. Kebanggaan ini terlihat dari pemasangan foto diri dalam baju seragam. Seragam TNI memang memiliki karisma tersendiri bagi masyarakat Indonesia. Hal ini terlihat pada banyaknya kasus-kasus pemakaian seragam TNI sebagai alat untuk menakut-nakuti atau "gagah-gagahan". Hasil
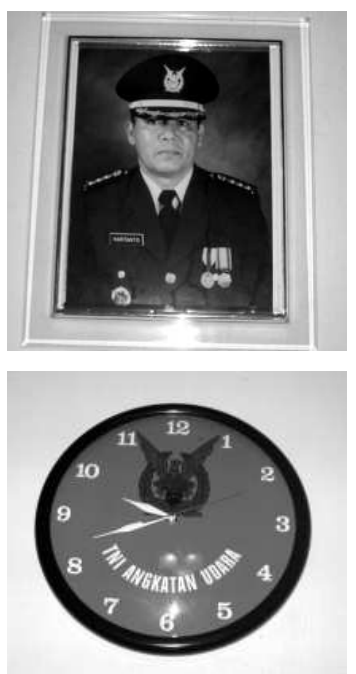

Gambar 14. Foto Diri dalam Seragam Dinas dan Jam Berlogo Angkatan
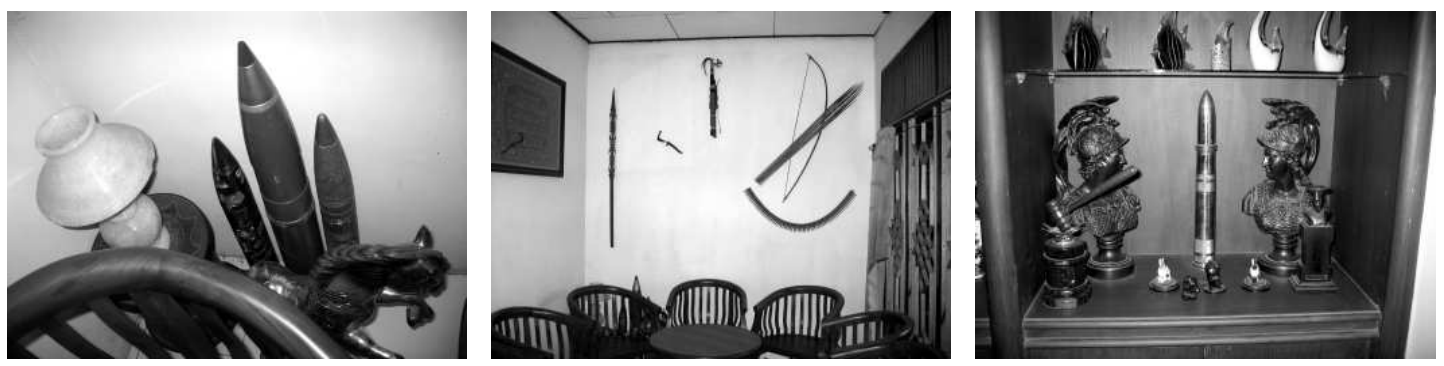

Gambar 13. Berbagai Macam Asesoris Berbentuk Peluru dan Busur Panah 
UNTAS

$\underset{\text { ISSN 1978-0702 }}{\text { RU }}$

wawancara juga mengungkapkan bahwa pemasangan foto diri dalam seragam lengkap tersebut dimaksudkan untuk memperingatkan tamu-tamu yang bermaksud jahat agar berpikir dua kali jika akan berbuat jahat terhadap pemilik rumah.

Signal yang terbaca dari kelompok seniman terlihat pada unsur pembentuk ruang yang menunjukan perwujudan ide estetis dan pandangan hidup seniman. Hasil wawancara menunjukkan konsep penghormatan terhadap alam dan prinsip untuk menyelaraskan diri dengan kehidupan sekitar menjadi konsep dalam mewujudkan ruang tamu seniman. Hal ini dapat dimaknai sebagai keunikan dan hasrat kreatif seniman untuk menunjukkan eksistensi dirinya. Profesi dan kehidupan seniman menuntut orisinalitas dalam berkarya agar dapat diakui dalam masyarakat luas. Seniman yang meniru-niru dan tidak memiliki ciri khas cenderung menjadi seniman kelas dua bahkan dituduh menjadi plagiat. Tuntutan profesi ini mendorong seniman untuk mempertahankan keunikan dirinya yang dituangkan dalam perwujudan fisik termasuk dalam ruang tamunya.

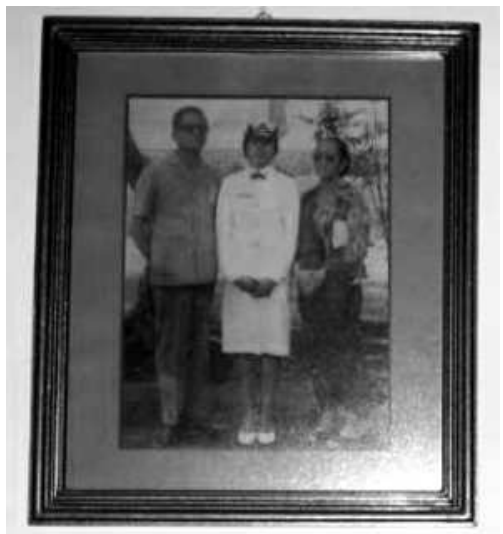

Gambar 15. Foto dalam Seragam Dinas Bersama Kedua Orang Tua
Beberapa seniman cenderung tidak memasang hasil karya seninya di ruang tamu melainkan menyediakan galeri khusus. Karya-karya seni yang terpasang di ruang tamu seniman seringkali merupakan hasil karya seniman lain. Hal ini menunjukkan apresiasi dan pengakuan terhadap sesama seniman. Pemasangan hasil karya seniman lain ini dapat pula dimaknai sebagai cita rasa estetis seniman yang meminjam karya seni untuk berkomunikasi dengan makna yang terkandung dalam karya seni tersebut.

Sebagian besar seniman juga tidak

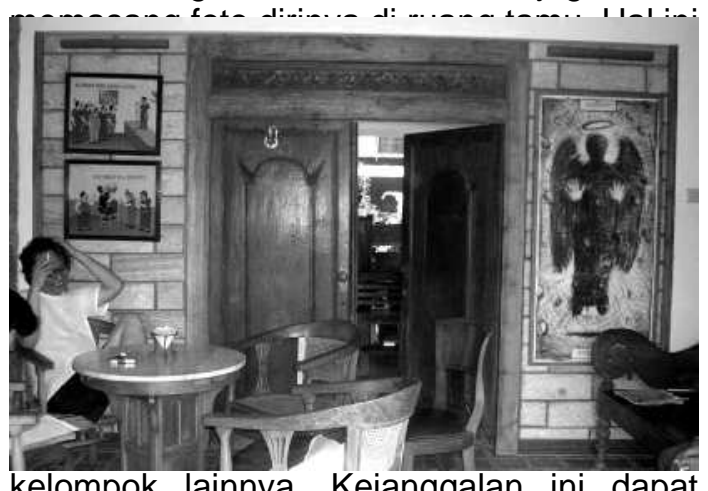

kelompok lainny ya Keiangqalan ini dapat dimaknai sqoan aithent seniman yang selalu berkecimpung dalam penciptaan seni. 

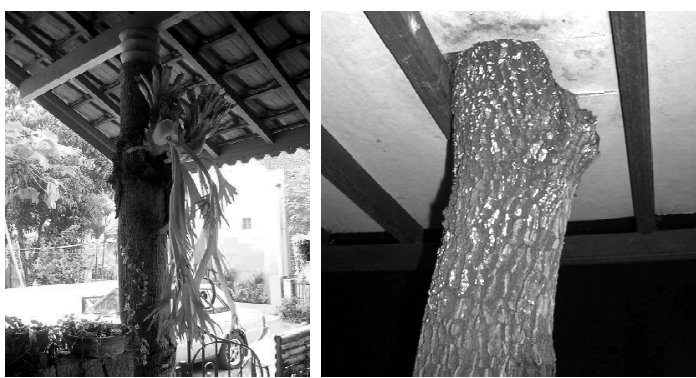

Gambar 17. Beberapa Upaya Menyelaraskan dan Menghormati Alam

Makna dalam Oposisi Biner

Makna yang terkandung dalam interior ruang tamu kelima status sosial dalam dipahami lebih jelas dengan menggunakan oposisi biner. Oposisi biner ini merupakan makna yang ditemukan dalam kelompok dan memiliki pasangan lawan katanya dalam satu kontinum linear. Makna-makna tersebut dapat dilihat dari pasangan oposisi biner dibawah ini:

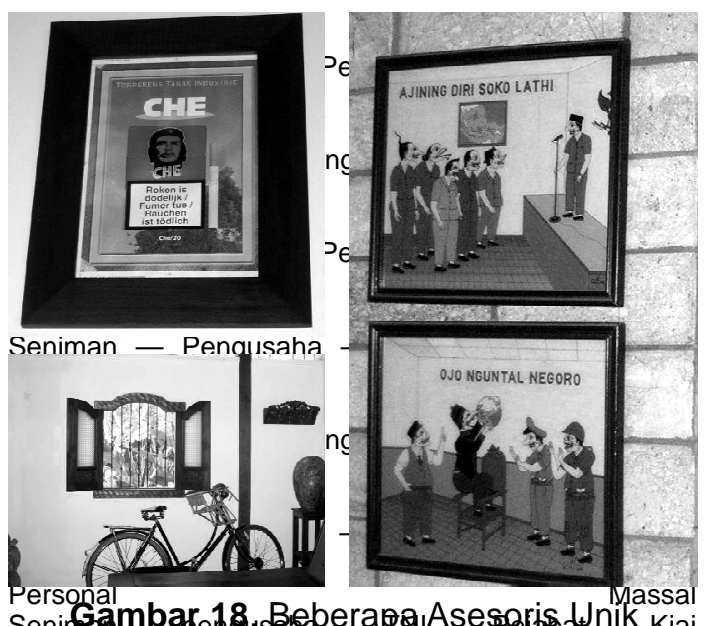

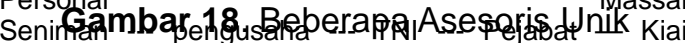
di Ruang Tamu Seniman

Interior ruang tamu kelima status sosial menunjukkan identitas setiap status sosial dengan berbagai macam penandanya. Makna-makna yang terkandung dalam interior kelima status sosial tersebut adalah :
Kesederhanaan-kemewahan, elit-awam, kebanggaan-bersahaja, artistik-apa adanya, idealistik-realistik, progresif-konservatif dan personal-massal. Makna-makna ini dapat dilihat dalam satu kontinum linear yang menunjukkan makna dominan yang terdapat dalam interior satu status sosial tertentu. Interior ruang tamu kiai memiliki makna dominan idealistik dan kesederhanaan, Seniman memiliki makna dominan artistik, unik, progresif dan personal. Interior ruang tamu staf TNI memiliki makna dominan realistik, sedangkan interior ruang tamu pejabat memiliki makna dominan awam. Pengusaha memiliki makna dominan kemewahan di Interior ruang tamunya.

Interior ruang tamu yang memiliki satu makna dominan tidak berarti hanya mengandung satu makna tersebut. Interior ruang tamu pejabat, pengusaha dan TNI dapat ditafsirkan mengandung makna lain meskipun tidak terlihat dominan jika dibandingkan dalam norma kelompok secara keseluruhan.

\section{DAFTAR PUSTAKA}

Altman, I. \& Taylor, D.A. 1973. Social Penetration the development of Interpersonal relationships. New York: Rinehart \& Winston.

Appignanesi, Richard. 1999. Postmodernism for Beginners. Bandung: Mizan.

Berger, Arthur Asa. 2000. Tanda-Tanda dalam Kebudayaan Kontemporer. Yogyakarta: Taira Wacana.

Bonta, Juan Pablo. 1979. Architecture and Its Interpretation. London: Lund Humphries.

Christian, James L. 1976. Philosophy an Introduction To The Art Of Wondering. San Fransisco: Rinehart Press.

Conran, Terence.1994. House Book. London: Conran Octopus Limited.

Eco, Umberto. 1979. A Theory Of Semiotics. Bloomington: Indiana University Press.

Lawson, Bryan. 2001. The Languange Of 


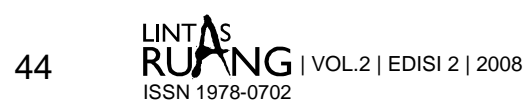

Space. Oxford: Architectural Press.

Scupin, Raymond \& De Corse, Christopher R. 1992. Anthropology a Global Perspective. New Jersey: Prentice Hall.

Suhady, Idup \& Sinaga, A.M. 2003. Wawasan Kebangsaan Dalam Kerangka Negara Kesatuan Republik Indonesia. Jakarta: Lembaga Administrasi Negara.

Sumintardja, Djauhari. 1978. Kompendium Sejarah:Arsitektur. Bandung: Yayasan Lembaga Penyelidikan Masalah Bangunan.

Susanto, Phil Astrid S. 1979. Pengantar Sosiologi dan Perubahan Sosial. Bandung: Binacipta.

Walker, John. A. 1989. Design History and The History of Design. London: Pluto Press. 